\title{
Slack resources, exploratory and exploitative innovation and the performance of small technology-based firms at incubators
}

\begin{abstract}
This paper aims to contribute to understanding about 1) how small technology-based firms while being constrained by limited resources, can still perform exploratory and exploitative innovation and 2) to extend knowledge about the role of slack resources in facilitating those innovation activities. By combining two streams of research on slack resources and innovation, our study constructed hypotheses predicting the role of slack resources in supporting innovation and firms' performance. Using a sample of 141 small technology-based firms from the Netherlands, Norway and the United Kingdom, this study tested several hypotheses predicting the impact of slack resources on performance. Using job growth as a dependent variable, the findings of this study shows that innovation activities translated the impact of slack resources on performance. While exploratory innovation plays a role as a mediator for the relationship between external slack and performance, the relationship between internal slack and performance is mediated by exploitative innovation.
\end{abstract}

Keyword: exploration, exploitation, innovation, internal slack, external slack, mediation. 


\section{Introduction}

The aim of this paper is twofold. First it looks to contribute to understanding about how in spite of being constrained by limited resources, small technology-based firms can still perform exploratory and exploitative innovation. Second, it aims to extend knowledge about the role of slack resources in facilitating those innovation activities. While the literature has been advocating the impact of exploratory and exploitative innovation on performance, the understanding of how slack resources support both innovation activities in the context of small technology-based firms is still under explored. Contrary to the assumption that small firm suffer from resource scarcity, recent studies have found strong evidence that small firms are able to perform both exploratory and exploitative innovation (e.g. Voss and Voss, 2013; Chang and Hughes, 2012; Ebben and Johnson, 2005; He and Wong, 2004). This indicates that small firms may possess the capability to acquire slack resources for supporting their innovation activities (Newbert, 2005; Nohria and Gulati, 1996).

This study is based on the argument that performing exploratory and exploitative innovation should co-align with the availability of slack resources (Edelman et al., 2005; Covin and Slevin, 1989; Venkataraman, 1989; Venkataraman and Camillus, 1984). As utilizable resources that can be diverted or redeployed for the achievement of a firm's goals (Voss et al., 2008; Greeve, 2007; George, 2005), slack resources provide not only safeguards against threats but also a flexibility to perform innovation activities (George, 2005; Daniel et al., 2004; Chen and Hambrick, 1995). However, studies on slack resources in the context of small firms are quite rare. For small technology-based firms, slack resources may not normally be found in the form of idle capacity, extra assets and/or surplus employees. In contrast, slack resources can be generated by restructuring the existing resources (Ebben and Johnson, 2005; Covin and Slevin, 1989) or can also be retrieved through the facilitation of intermediaries' agency, such as a university or business incubator (Boh et al., 2012; Peters et al., 2004). For small technology-based firms, incubation support may bring additional resources in the form of funding, grants or access to a research facility and/or workshop, which allow small technology-based firms to perform new innovation activities.

This study looks to extend knowledge about the role of slack resources in in the context of small technology-based firms located at incubators. As incubated firms benefit from low transaction and search costs in acquiring resources, they are more likely to create slack resources to support innovation activities. Hypotheses were constructed and tested using data collected from 141 small technology-based firms in The Netherlands, Norway and the United Kingdom. This study contributes to knowledge and the emerging dialogue around incubation support and innovation in the following ways. First, we respond to scholar's call for more evidence that links firm strategy to firm performance (Teece, 2010). While previous research has asserted the positive link between these aspects, most studies focus on established firms and overlook the challenge faced by small technology-based firms. In focusing on slack resources, we extend understanding to show how these firms perform their innovation activities. Secondly, this study provides new empirical evidence to 
show that even in small firms slack resources can be generated and used to support innovation activities. This finding will help support policy aimed at enhancing the innovation activities of small firms. Finally, this study contributes to the call for more policy oriented research examining new ways to support innovation activities of small technology-based firms (Phan et al., 2005; Peters et al., 2004) and to strengthen entrepreneurial support provided by business incubators (Mian et al., 2016).

\section{Literature review}

\subsection{Exploratory and exploitative innovation and the role of slack resources}

The need for employing exploratory and exploitative innovation was introduced by Tushman and O'Reilly (1996) when they hypothesized the concept of the ambidextrous organisation. They described ambidextrous firms as being those that have the capabilities to compete in existing markets but, at the same time, develop new products or services (Turner et al., 2013; O'Reilly and Tushman, 2011). Studies have found that excelling at both exploratory and exploitative innovation is vital for successful performance (Chang and Hughes, 2012; Hughes et al., 2010; Raisch et al., 2009; Sheremata, 2000; Tushman and O'Reilly, 1996). However, the basic problem for every firm is to engage in exploitation and, at the same time, devote enough resources for exploration (He and Wong, 2004; Levinthal and March, 1993). This is problematic because the two activities come from different

experiences. With exploitation, experience is created through refinement, routinization, and implementation of current knowledge (Rothaermel and Deed, 2004; Benner and Tushman, 2003). Exploitation includes efficiency and convergent thinking to harness current capabilities and continuously improve product offerings (Wadhwa and Kotha, 2006; Rothaermel and Deed, 2004; Levinthal and March, 1993). However with exploration, experience occurs through search, discovery, novelty and experimentation and it is through these types of activities that new combinations of knowledge take place (Wadhwa and Kotha, 2006; Rothaermel and Deed, 2004; Benner and Tushman, 2003; Levinthal and March, 1993).

While there have been many factors proposed by scholars in explaining the antecedents of the ambidextrous organisation (Lubatkin et al., 2006; He and Wong, 2004), a consistent argument is that slack resources provides much needed resources to perform exploration and exploitation (Vos et al., 2008; Nohria and Gulati, 1996). Studies on slack resources have been around for several years (Vos et al., 2008; George, 2005; Daniel et al., 2004; Nohria and Gulati, 1996; Sharfman et al., 1988; Bourgeois and Singh, 1983; Bourgeois, 1981). Cyert and March (1963) defined slack resources as the disparity between the resources available to the organization and the payment required to maintain the coalition. Bourgeois (1981) added that slack resources are actual or potential resources which allow an organisation to adapt successfully to internal pressures for adjustment or to external pressures for a change in policy, as well as to initiate changes in strategy with respect to the external environment. While many scholars have mainly measured slack resources in financial terms (Nohria and Gulati, 1996; Sharfman et al., 1988; Bourgeouis and Singh, 1983; Bourgeouis, 1981), the literature has 
evolved and the concept of slack resources now includes other resource characteristics such as absorbed and unabsorbed resources (Singh, 1986), immediately and deferred resources (Finkelstein and Hambrick, 1990), available, recoverable, and external slack (Bourgeouis and Singh, 1983). More recently, studies have broadened the definition and have covered more general organisational resources such as potentially utilizable resources that can be diverted or redeployed for the achievement of organizational goals (George, 2005).

In the context of small firms, resource scarcity does not prevent the firms from performing both exploratory and exploitative innovation (He and Wong, 2004). Slack resources can be created as small firms differ significantly compared to large firms in terms of their impediments in dealing with those activities (Lubatkin et al., 2006). Small firms do not recognise the presence of hierarchical levels in their organisations (Dalton et al., 1980). Therefore, they tend to be flexible in organising and acquiring slack resources from internal and external sources.

Based on the location of slack resources within an organisation, this study considers slack resources in two forms. First, slack resources can be manifested in the form of internal slack. This slack is a type of resource that is available and located within the firms but not yet committed. As internal slack are often absorbed in ongoing operational activities, they include unexploited opportunities to increase outputs such as margins or revenues from customers and innovation to increase efficiency. They also cover financial and human capital and in some cases, some idle capacity on research or production that is ready to be allocated for new activities. The second form of slack is external slack. This type of slack is a type of resource that is not currently available as a part of a firm's assets and resources. These unabsorbed resources are external to the firm but can be redeployed and recovered through a firm's special arrangement (Tan and Peng, 2003; Nohria and Gulati, 1996). This type of slack is often generated as a result of the firm's social capital or support from intermediary organisations such as a university and/or business incubator (Lamine et al., 2015; Mian et al., 2012; Tan and Peng, 2003). With their support, small firms are enabled to potentially discover a new opportunity, strengthen their current offering or respond to the need for exploitation or exploration quickly.

\subsection{Slack resources and the performance of small technology-based firms}

The relationship between slack resources and performance has been the subject of debate in many studies which appears to be dichotomised into two propositions, a positive and a negative impact of slack resources. The resource-based view theory (Penrose, 1959) and behavioural theory of the firm (Cyert and March, 1963) offer support on arguments that slack resources provide a buffer for threats and facilitate a proactive strategy. One of the main arguments within this stream of studies is that slack resources play a crucial role in resolving conflicts and preventing the organisation from breaking apart (Cyert and March, 1963). Slack resources also create buffers that reduce information processing and coordination costs (Voss et al., 2008; Daniel et al., 2004; Smith et al., 1991; Levinthal 
and March, 1981; Galbraith, 1974). Those who propose a negative relationship argue that slack resources result in organisational inefficiency (Jensen, 1986; March and Simon, 1958). Idle resources may also create inefficiency as this type of slack resource encourages self-serving managerial behaviours that damage performance. Using agency theory, scholars suggest that slack may create irrational optimism (George, 2005). As a result, managers may pursue their own project interests (Stroh et al., 1996; Jensen, 1986). Given the wide range of evidence in the literature, some studies have found merit in both arguments. Scholars such as Bourgeois (1981) and Cheng and Kesner (1997) argue that the relationship between slack resources and performance can be described as a curvilinear relationship.

However, in the context of small technology-based firms, we argue that the relationship between slack and performance is positive. With regards to internal slack, this type of slack resource brings positive effects on the performance as it eases restrictions and improves the strategic choices of small firms to perform new investments. As internal slack is derived from underutilized operational resources, internal slack also allows experimentation and risk taking which may have a positive impact on innovativeness and performance (Daniel et al., 2004; Nohria and Gulati, 1999; Damanpour, 1991). In the case of large firms, internal slack is absorbed and generally tied to a specific purpose of production which is relatively difficult to reallocate to alternative uses. As a result, having a high amount of internal slack may create problems in production, logistics and inventories. This is not the case for small firms, as their production process, management structure and decision making process are still flexible. Having a high degree of internal slack is also not a sign of their incapability to exploit market opportunities. Many of small technology-based firms target a niche market. This market may bring positive financial return due to low market competition, a situation in which small technology-based firms may develop internal slack without threating their survival and growth. Therefore, we propose the following hypothesis.

H1. In small technology-based firms, internal slack is positively associated with firm performance.

Likewise, we also argue that external slack brings positive impacts on the performance of small technology-based firms. External slack is created from a firm's ability to access additional resources. As resources are limited, the effort in building social capital and networks may help small technologybased firms to find support for the development of a new product or market. External slack in the form of relational resources from suppliers and customers may provide buffers and a predictable stream of revenue that facilitates efficiency in planning and reduces costs. In addition, incubation support may provide access to facilities when small firms intend to explore new innovation. For that reason, we argue that accumulating external slack may have a positive implication on performance. Thus, we posit the following hypothesis. 
H2. In small technology-based firms, external slack is positively associated with firm performance.

\subsection{Innovation activities as a mediation for the impact of slack on performance}

While the previous hypotheses predicted the direct impact of slack resources on performance, the following hypotheses considers the role of slack resources in supporting exploitative and exploratory innovation which indirectly influence the performance. In developing the hypotheses, we followed studies that used a contingency theory approach that assumes a fit between available resources and that a firm's particular strategy leads to enhanced performance (Chrisman et al., 1999; Chandler and Hanks, 1994; Edelman et al., 2005). However, we also argue that the types of slack resources should meet the need of certain innovation activities.

The next hypothesis predicts the relationship between internal slack and exploitative innovation, where the later plays a mediation role. Small firms need to acquire internal slack to perform experiments and for risky projects (Nelson and Winter, 1982; Hambrick and Snow, 1977). Internal slack allows the execution of exploitation projects by providing buffers for uncertain success, absorbing failure, bearing the cost of developing innovation and fostering a culture of experimentation (George, 2005; Bourgeois, 1981; Rosner, 1968; Mansfield, 1963). A firm pursuing exploitation in a market or technology domain needs innovative, creative and strong technical employees (Chandler and Hanks, 1994). In contrast, internal slack may not be relevant for exploration projects as its presence may weaken a firm's adaptive response to an environmental shift. Rather than providing small firms with the support to explore new opportunities, internal slack may actually inhibit a small firm's response strategy by slowing the reaction of competitor's moves or sudden market shifts (Cheng and Kesner, 1997). For that reason, we believe that internal slack will exert a positive influence on exploitative innovation of small technology-based firms.

To test the indirect impact of slack resources on performance, we followed Chrisman et al. (1999) and Edelman et al. (2005) that model the co-alignment between resources and strategy as a mediated relationship. We posit that exploitative innovation play a role as a mediator and transforms the impact of internal resources on performance. Therefore, we propose the following hypothesis.

H3. Exploitative innovation moderates the relationship between internal slack and the performance of small-technology-based firms.

External slack are resources which are not currently possessed by firms but can be extracted for innovation. For small technology-based firms, external slack is one possible source of support for any exploratory activities (Herold et al., 2006). In developing new projects, small technology-based firms often require access to resources and knowledge that are external to the firms. Besides access to research from university, small technology-based firms need to access research and workshop facilities. In this case, access to network resources provides relaxation of controls and represents a 
source of resources to deal with uncertainties (Lamine et al., 2014; Nohria and Gulati, 1997). Funding for research is also necessary for facilitating exploratory innovation. As a result, external slack supports innovation activities by allowing exploration projects to be executed (Nooteboom et al., 1997). Based on the above argument, we argue that the impact of external slack on performance is mediated by explorative innovation. To test our argument, we propose the following hypothesis.

H4. Explorative innovation moderates the relationship between external slack and the performance of small technology-based firms.

\section{Research method}

\subsection{Sampling}

The context of this study was small technology-based firms located at incubators in the Netherlands, Norway and the United Kingdom. The sample was selected as being representative of the current trend in northern European countries which is towards creating knowledge-based economies through the creation of small technology-based firms. The countries chosen tend to be similar in their perspectives about universities being a source for creating academic spin-offs, i.e. small technologybased firms aiming to commercialise knowledge and innovation developed at university. The data collection process was conducted in the period 2009 to 2010. In total, a list of more than 200 firms located at the incubators was generated. After several attempts of contacting the firms, we succeeded to have valid interviews with 141 small technology-based firms.

The sample for this study was derived from the following delineation: (1) participants had to be established as technology-based firms. Most of the firms in the study have commercialised patented innovations from universities. In order to control the effect of internal firms' capability, this study selected academic spin-offs. Corporate spin-offs or technology-based firms founded by serial entrepreneurs were excluded as it was anticipated they may possess better capability in generating slack resources. (2) The sample firms were located at the incubators or received incubation support at the time of the study. As the study intends to control the ability of firms in performing innovation and acquiring slack resources, the selection ensured that the sample firms were in a similar stage of development, experienced similar obstacles and received incubation support.

Table 1 shows the description of the sample. In the Netherlands, the selected firms are technology-based firms from TU Delft. These firms received a comprehensive set of support measures, including a room and facilities in the incubator building, and additional value-added support. The second sample was collected at Trondheim in Norway. Small technology-based firms created from NTNU and SINTEF Trondheim were the target of this study. The companies were located at two incubators, Gloshaugen Innovation Center and Leiv Eriksson Nyfotek. Both incubators offered access to a range of services, including business counselling, insurance, legal services, book keeping, public relations, etc. The last sample was derived from small technology-based firms which were located at the Daresbury Science and Innovation centre and Lancaster University business 
incubator. The small firms have commercialised technology and innovation developed from universities, namely Lancaster University, the University of Liverpool and the University of Manchester. In the UK, most of the firms were relatively small with more than $50 \%$ of the total sample having less than 10 employees. The proportion is similar to the firms in the Netherlands. However, the majority of the firms in the UK were in the ICT and life science sectors while in the Netherlands, the sample was diverse. In Norway, the percentage of the small firms with employees 26-50 was relatively high. Compared to the sample in the UK and the Netherlands, the firms in Norway had grown relatively fast. In the overall sample, the firms with high employment were ICT, design and service firms.

Table 1. The description of samples

\begin{tabular}{|c|c|c|c|c|}
\hline Location & $\begin{array}{l}\text { Number of } \\
\text { firms }\end{array}$ & $\begin{array}{l}\text { Average } \\
\text { ages (SD) }\end{array}$ & $\begin{array}{l}\text { Average number } \\
\text { of employees } \\
\text { (FTE) }\end{array}$ & Type of industry \\
\hline $\begin{array}{l}\text { United } \\
\text { Kingdom }\end{array}$ & 58 firms & $4.23(3.1)$ & $\begin{array}{l}0-5: 20.7 \% \\
6-10: 32.8 \% \\
11-25: 25.9 \% \\
>25: 20.7 \%\end{array}$ & $\begin{array}{l}\text { ICT: } 44.7 \% \text {; Life science: } 32.8 \% \text {; } \\
\text { Advanced engineering: } 3.4 \% \text {; Design } \\
\text { and services: } 15.5 \% \text {; Other: } 3.4 \%\end{array}$ \\
\hline $\begin{array}{l}\text { The } \\
\text { Netherlands }\end{array}$ & 55 firms & $5.12(4.7)$ & $\begin{array}{l}0-5: 30.9 \% \\
6-10: 29.1 \% \\
11-25: 21.8 \% \\
>25: 18.2 \%\end{array}$ & $\begin{array}{l}\text { ICT: } 27.3 \% \text {; Life science: } 9.1 \% \text {; } \\
\text { Advanced engineering: } 23.6 \% \text {; Design } \\
\text { and services: } 29.1 \% \text {; Other: } 10.9 \%\end{array}$ \\
\hline Norway & 28 firms & $4.45(2.2)$ & $\begin{array}{l}0-5: 35 \% \\
6-10: 7.1 \% \\
11-25: 14.3 \% \\
>25: 42.9 \%\end{array}$ & $\begin{array}{l}\text { ICT: } 21.4 \% \text {; Life science: } 14.3 \% \text {; } \\
\text { Advance engineering: } 17.9 \% \text {; Design } \\
\text { and services: } 39.3 \% \text {; Other: } 7.1 \%\end{array}$ \\
\hline
\end{tabular}

The data was derived from a questionnaire-based survey. The questionnaire included pre-defined answers as well as open questions. Prior to the main survey, several pilot in-depth interviews were conducted to test the reliability of the measurements. The in-depth interviews encompassed five firms to pre-test the questionnaire and another five firms to collect in-depth information to give us understanding of the firms' innovation activities, characteristics and the performance of their business. The interviews also included open-ended questions related to exploitation and exploration activities, such as 'how do you exploit your current market?', 'how do you develop a new market/product?' Additional pointed questions, such as how the respondents managed to acquire resources for those new exploitation and exploration activities were also asked. In addition, we had 
several formal and informal meetings with the managers of the incubators, university's technologytransfer and knowledge exchange officers.

Although the context of this study is small technology-based firms located at incubators, this study faced challenges. Similar to other studies which use incubators for their context, one issue was how to tackle survival bias because of the systematic process applied by the incubator prior to incubation. Firms at incubators are normally selected according to a number of criteria (e.g. business plan, financial estimation, level of innovation, etc) to assess their future changes (Phan et al., 2005). Firms with a high risk or with a less promising value offering are not usually accepted in the program. This selection process may induce relatively low failure rates, suggesting an overestimation of the factors that may contribute to the performance of firms. To deal with the issue, we followed previous studies by examining a control group such of firms located on and off incubators (e.g. Colombo and Delmastro, 2002; Löfsten and Lindelöf, 2005; Westhead and Storey, 1994). Additional data were collected and analysed to assess the differences compared to our sample. Through interviews with five small technology-based firms without incubation support, we found no evidence of significant different in terms of performance and innovation activities. However, small technology-based firms located outside incubators have different arrangement of resources and networks composition compared to incubated firms. Because of this limitation, the finding of this study should be carefully interpreted in their context of incubated firms. To increase the credibility of the sample, we carefully selected the sample to capture the dynamic and characteristics of small technology-based firms in the incubators. We focus exclusively on firms, which have already launched their products in the market while, at the same time, have performed both exploration and exploitation activities.

\subsection{Measurements}

Performance. The performance variable of the study was measured as job growth, i.e. an average annual job growth between 2006-2009. We used job growth because financial measurement is biased toward the impact of exploration activities. Compared to returns from exploitation, the outcomes of exploration are less certain, more remote in time and organizationally more distant from the locus of action and adaption (March, 1991).

Internal slack. To measure this variable, we followed the measurement of slack developed by Nohria and Gulati (1996). The respondents were asked the following questions. (1) Suppose, if due to some sudden development, $10 \%$ of the time of all the people working on your main project has to be spent on work totally unconnected with the main project, how seriously will your project/output/target be affected over the next year? (2) Suppose if due to some sudden development, your budget is reduced by $10 \%$, how significantly will your project/output/target be affected over the next year? Following Nohria and Gulati (1996), the respondents were given five choices ranging from 1, 'our main project or output will not be affected' to 5, 'the project will be delayed or output will fall by $20 \%$ or more'. 
The midpoint, 3 , could be chosen to indicate that the project would delay or output would fall by about $10 \%$.

External slack. We adapted the measurement constructed by Chattopadhyay et al. (2001). The respondents were asked to answer the following questions (1) to what extent does your firm have difficulty in obtaining external funds to pay the cost of activities outside the main project? (Reversecode) (2) To what extent does your firm have difficulty in getting access to research facilities and workshops? (Reverse-code), (3) To what extent does your firm have difficulty in building new business networks? (Reverse-code). The respondents were expected to answer the questions using five-Likert scales with 1, 'Extremely/very difficult', and 5, 'Extremely/very accessible'.

Exploratory innovation. To measure exploratory and exploitative innovation, we generated items on a five-Likert scale with 1 representing 'strongly disagree' and 5 representing 'strongly agree' based on previous studies conducted by Abernathy and Clark (1985), Benner and Tushman (2003), Danneels, (2002) and Jansen et al. (2006). In measuring exploratory innovation, the respondents were asked to consider the following statements (1) We commercialise products and services that are completely new to our firms, (2) We frequently explore new opportunities in new markets, (3) We experiment with new products and services in our markets. These statements were intended to capture the extent to which firms depart from existing knowledge and pursue innovation for new customers or markets.

Exploitative innovation. This variable looked to capture the extent to which firms build on existing and current knowledge and capability to meet the needs of existing customers. The respondents were asked their opinions about the following statements; (1) We frequently refine and improve existing products and services, (2) We introduce improved, existing products and services for our markets, and (3) We increase economies of scales in existing markets or expand services for existing customers. The respondents were expected to answer the questions using five-Likert scales with 1, 'strongly disagree', and 5 , 'strongly agree'.

Size and age of firm. To control the impact of innovation activities and slack, we employed several control variables. We collected data on firm size as the number of full-time employees. Age was measured with a single item on founding date of the firm.

\subsection{Method of analysis}

To analyze the data, structural equation modeling was used. Structural equation modelling is commonly used to test mediating relationships as all of the relevant paths are directly tested while measurement error and feedback are also incorporated directly into the model (Edelman et al., 2005; Venkataraman, 1989; Baron and Kenny, 1986 ). Following methodological steps in Edelman et al. 
(2005), we inspected the data for any possible abnormalities. We ran a Monte Carlo simulation as suggested by Muthén and Muthén (2002) to determine whether our sample size was adequate for the analysis. For the simplest CFA model with normally distributed continuous factor indicators and no missing data, a sample size of 130 is needed for power of .81 to reject the hypothesis that the factor correlation is zero. By adding the complication of missing data, a sample size of 165 is required for power of .81. Based on the result, we found strong support for using the sample to perform the analysis. We also followed Kline (1998) and checked for missing data, the normality of the data distribution, outliers, and multicollinearity. To handle the problem of missing data, we used mean substitution, which is a technique in which the variable means are used to replace missing values (Afifi and Elashoff, 1966). The missing value procedure did not cause any statistically significant bias in the data; no statistically significant differences between the original and the missing value means substituted data series was observed. In addition we also checked for the outliers using Mahalanobis distance. Mahalanobis distance is a measure of the distance of an observation from the set of $x$-value means. In all of the observations in our data, the Mahalanobis distance is between the recommended values of 0 and 1 indicating that outliers are not a problem in our dataset (Kleinbaum et al., 1988). Lastly, we also checked the data for multicollinearity. In all cases, the variance inflation factor (VIF) statistic was under 1.5, which is well under the 10.0 cut-off that indicates problematic data collinearity (Kleinbaum et al., 1988). Overall, we can conclude that our data does not violate normality or multicollinearity assumptions.

\section{4. $\quad$ Result}

\subsection{Descriptive statistics}

Table 2 presents the mean, standard deviation, and correlations of all the variables. The correlation result shows that the performance was correlated to the other variables as predicted. There was a strong correlation between internal slack and external slack. The variable of internal slack was significantly related to exploitative innovation as was the variable of external slack to exploratory innovation. In addition, the correlation between exploitation and exploration was also found significant indicating that both activities were performed simultaneously. Overall, we found partial support for the relationship stated in the hypotheses.

Table 2. Descriptive statistics and correlations

\begin{tabular}{|l|l|l|l|l|l|l|l|l|l|}
\hline & Variable & Mean & SD & 1 & 2 & 3 & 4 & 5 & 6 \\
\hline 1 & Job growth & 2.97 & 1.56 & & & & & & \\
\hline 2 & Internal slack & 2.58 & .81 & $.20 \dagger$ & & & & & \\
\hline 3 & External slack & 3.17 & .87 & .15 & $.26^{*}$ & & & & \\
\hline 4 & Exploratory & 2.84 & .88 & $.33^{* *}$ & .15 & $.34^{* *}$ & & & \\
\hline
\end{tabular}




\begin{tabular}{|l|l|l|l|l|l|l|l|l|l|}
\hline & innovation & & & & & & & & \\
\hline 5 & $\begin{array}{l}\text { Exploitative } \\
\text { innovation }\end{array}$ & 3.00 & .89 & $.37 * *$ & $.22^{*}$ & .09 & $.33^{* *}$ & & \\
\hline 6 & Size of firms & 6.20 & 2.10 & .12 & .11 & .02 & .02 & -.09 & \\
\hline 7 & Age of firms & 5.43 & 2.84 & $.23 \dagger$ & .01 & .09 & .8 & -.04 & -.15 \\
\hline
\end{tabular}

$\dagger: p<.10 ; *: p<.05 ; * *: p<.01$

To study the assessment of the measurement model, several statistical tests were performed. Regarding individual item reliability, all of the constructs had loadings over 0.707 . Table 5 shows the average variance extracted (AVE) that show for all the reflective indicators, AVE values exceeded the value of 0.50 . Tests for discriminant validity were employed to measure the extent to which the constructs differs from others. Overall, we found that each construct was related more strongly to its own measures than to the others.

Table 3. Loadings and cross-loadings for the measurement model

\begin{tabular}{|l|r|r|r|r|}
\hline & $\begin{array}{r}\text { Exploitative } \\
\text { innovation }\end{array}$ & $\begin{array}{r}\text { Exploratory } \\
\text { innovation }\end{array}$ & \multicolumn{1}{c|}{$\begin{array}{c}\text { Internal } \\
\text { slack }\end{array}$} & \multicolumn{1}{c|}{$\begin{array}{c}\text { External } \\
\text { slack }\end{array}$} \\
\hline Exploitation1 & $\mathbf{0 . 7 7 0 9}$ & 0.1852 & 0.4373 & 0.3703 \\
\hline Exploitation2 & $\mathbf{0 . 8 1 8 9}$ & 0.2022 & 0.4722 & 0.3981 \\
\hline Exploitation3 & $\mathbf{0 . 7 6 1 2}$ & 0.1351 & 0.4733 & 0.4664 \\
\hline Exploration1 & 0.1088 & $\mathbf{0 . 7 5 0 9}$ & 0.2120 & 0.2000 \\
\hline Exploration2 & 0.1266 & $\mathbf{0 . 7 0 2 7}$ & 0.2010 & 0.2610 \\
\hline Exploration3 & 0.1911 & $\mathbf{0 . 7 5 0 6}$ & 0.1939 & 0.1721 \\
\hline Internal1 & 0.5001 & 0.2372 & $\mathbf{0 . 8 5 2 8}$ & 0.6514 \\
\hline Internal2 & 0.501 & 0.2414 & $\mathbf{0 . 8 7 8 6}$ & 0.6215 \\
\hline External1 & 0.4764 & 0.2320 & 0.6901 & $\mathbf{0 . 8 6 6 4}$ \\
\hline External2 & 0.4640 & 0.2915 & 0.6842 & $\mathbf{0 . 8 7 3 7}$ \\
\hline External3 & 0.4099 & 0.2670 & 0.6590 & $\mathbf{0 . 9 0 0 2}$ \\
\hline
\end{tabular}

Table 4. Test for convergent and discriminant validity

\begin{tabular}{|l|l|l|l|l|l|l|}
\hline & AVE & $\begin{array}{l}\text { Composite } \\
\text { reability }\end{array}$ & $\begin{array}{l}\text { Exploitative } \\
\text { innovation }\end{array}$ & $\begin{array}{l}\text { Exploratory } \\
\text { innovation }\end{array}$ & $\begin{array}{l}\text { Internal } \\
\text { slack }\end{array}$ & $\begin{array}{l}\text { External } \\
\text { slack }\end{array}$ \\
\hline $\begin{array}{l}\text { Exploitative } \\
\text { innovation }\end{array}$ & 0.6087 & 0.7320 & $\mathbf{0 . 7 8 3 7}$ & 0 & 0 & 0 \\
\hline $\begin{array}{l}\text { Exploratory } \\
\text { innovation }\end{array}$ & 0.67876 & 0.8025 & 0.6066 & $\mathbf{0 . 7 3 4 7}$ & 0 & 0 \\
\hline
\end{tabular}




\begin{tabular}{|l|l|l|l|l|l|l|}
\hline Internal slack & 0.5590 & 0.7587 & 0.1969 & 0.2631 & $\mathbf{0 . 8 6 5 7}$ & 0 \\
\hline External slack & 0.7042 & 0.8120 & 0.5287 & 0.7795 & 0.2892 & $\mathbf{0 . 8 8 0 1}$ \\
\hline
\end{tabular}

\subsection{Analysis}

To test hypothesis 1 and 2, we employed hierarchical testing (Kline, 1999). The testing compares the goodness-of-fit (chi-square) of different models by assessing whether the observed relationship differs significantly from the hypothesized model. Although the test is sensitive to the complexity of the model, hierarchical testing considers that a nonsignificant chi-square indicates a good fit. In our study, hypothesis 1 and 2 are direct models which test the relationship between the independent variables (slack resources and innovation activities of exploration and exploitation) and the dependent variable of firm performance. The result shows that the chi-square test statistic is significant at $P \leq .01$ for this model $\left(\chi^{2}=100.2\right)$, indicating that the model is not a good representation of the data. As a result, we could not confirm both hypotheses. This result is in contrast to the previous study that has found either a positive or negative impact of slack on firm performance. This insignificant finding may be caused by the use job growth as a performance measurement. In fact, there is a long time-lag between the cause and the effect. Another explanation is because the context of this study is small technologybased firms. In this case, the performance is not measured directly by the ability to generate slack resources. Many firms have their slack resources but this does not mean they perform badly in terms of producing innovative products or services.

For, the indirect model which tests the mediating relationship between the independent variable of slack resources (internal and external) and the mediating variable of innovation activities (exploratory and exploitative innovation), the chi-square is not significant $\left(\chi^{2}=17.0\right)$; indicating that the model fits the data. The chi-square is also not significant for the saturated or partially mediated model but, according to Kline (1999), given the fit and significance of the indirect model, no additional paths are required (Kline, 1998). Therefore, we have support for hypotheses 3 and 4 which argue that innovation activities fully mediate the relationship between slack resources and firm performance. Table 5 summarizes the fit statistics between the direct and indirect models.

Table 5. Structural equation model hierarchical testing

\begin{tabular}{|l|l|l|l|l|l|l|}
\hline Model & $\chi^{2}$ & $\chi^{2} / d f$ & $d f$ & $P$ & GFI & AGFI \\
\hline Direct model (Slack resources - Performance) & 100.2 & 4.88 & 21 & .000 & .87 & .77 \\
\hline $\begin{array}{l}\text { Indirect model (Slack resources - Innovation } \\
\text { activities - Performance) }\end{array}$ & 17.0 & 1.65 & 13 & .21 & .98 & .94 \\
\hline
\end{tabular}

In hypotheses 3 and 4, we make a prediction that specific paths exist in the mediated model (indirect). To test the hypotheses, we examined the path coefficients and the critical ratios for the indirect model. 
To ensure that the indirect, fully mediated model fits the data well, we used multiple fit criteria to rule out measuring biases inherent in the various methods (Hair et al., 1995). The chi-square divided by the degrees of freedom was 1.67 , which is under the suggested ratio of 2 , for the hypothesized indirect model, and the $P$ value is .21, which is greater than the suggested .05 (Schumacker and Lomax, 1996). Moreover, the adjusted goodness-of-fit (AGFI) of the models was .91, indicating a good fit with the data (Hoyle, 1995). In line with the previous test, the goodness-of-fit index (GFI) was .94, well above the .90 acceptable levels (Hair et al., 1995). The result from incremental fit index (IFI) was .97 exceeded the recommended value of .90 . Finally, the root-mean-square residual (RMR) was a very acceptable .02 for the indirect model, indicating a low difference between the observed and modelimplied covariances (Kline, 1998).

Table 6. Indirect model measurement values (Hair et al., 1995)

\begin{tabular}{|l|l|l|}
\hline Model & Value & Recommended value \\
\hline$\chi^{2}(d f)$ & $17.04(13)$ & \\
\hline$\chi^{2} / d f$ & 1.67 & $\leq 2.0$ \\
\hline P & .21 & $\geq .05$ \\
\hline AGFI & .91 & $\geq .90$ \\
\hline GFI & .94 & $\geq .90$ \\
\hline AGFI & .91 & $\geq .90$ \\
\hline IFI & .97 & $\geq .90$ \\
\hline RMR & .02 & Very low values \\
\hline
\end{tabular}

The next table shows the paths, standardize estimates and the t-value for the indirect model. In hypothesis 3 , we predicted a positive and significant relationship among three variables, internal slack, exploitative innovation and performance. The finding shows that the path between internal slack and exploitative innovation is significant while the path between exploitative innovation and performance is also significant. The finding indicates strong support for hypothesis 3 . In hypothesis 4 , we predicted a mediation relationship played by exploratory innovation in the relationship between external slack and performance. With regards to the path between external slack and exploratory innovation, we found strong support. However, the path between exploratory innovation and performance is rather weak but still significant. In this case, the finding indicates a confirmation for hypothesis 4 . Figure 1 illustrates the result of the hypotheses testing.

Table 7. Structural parameters, hypotheses and model measurement values

\begin{tabular}{|l|l|l|l|}
\hline Path & Hypothesis & $\begin{array}{l}\text { Standardized } \\
\text { estimate }\end{array}$ & value \\
\hline
\end{tabular}




\begin{tabular}{|l|l|l|l|}
\hline Internal slack - exploitative innovation & $\mathrm{H} 3$ & .228 & $2.50^{* *}$ \\
\hline Internal slack - exploratory innovation & & .002 & .833 \\
\hline External slack - exploitative innovation & & -.104 & -1.30 \\
\hline External slack - exploratory innovation & $\mathrm{H} 4$ & .203 & $2.99^{* *}$ \\
\hline Exploitative innovation - performance & $\mathrm{H} 3$ & .310 & $2.83^{* *}$ \\
\hline Exploratory innovation - performance & $\mathrm{H} 4$ & .189 & $1.96^{*}$ \\
\hline Size of firm - performance & & .012 & .702 \\
\hline Age of firm - performance & & .104 & 1.45 \\
\hline
\end{tabular}

$\dagger: p<.10 ; *: p<.05 ; * *: p<.01$

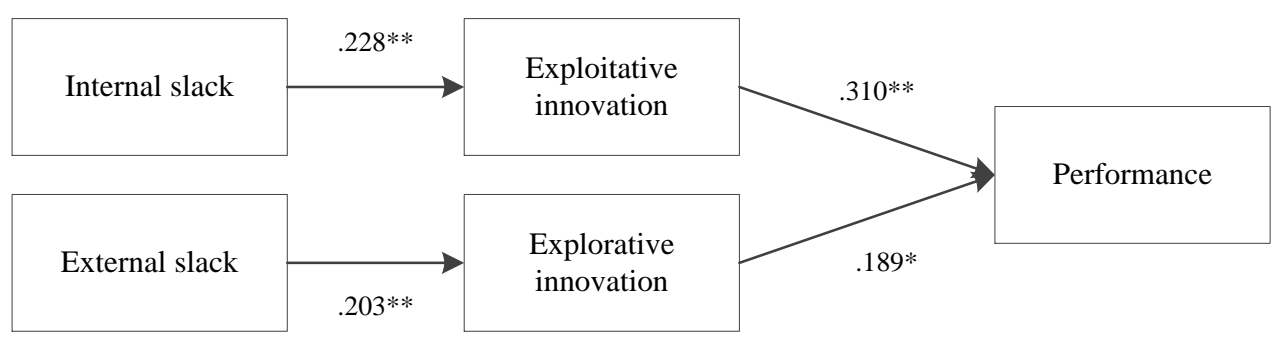

Figure 1. The result of hypothesis testing

\section{Conclusion}

This study aimed to examine the role of slack resources in the context of small technology-based firms. While conducting innovation activities is seen as the key for survival and growth of small firms, slack resources has rarely been considered as a catalyst for innovation. With the objective to improve our understanding on this subject, this study constructed several hypotheses predicting direct and indirect impact of slack resources on performance. The finding of this study reveals that exploratory and exploitative innovation mediates the relationship between slack resources and performance.

With regard to the internal slack, the impact on performance is mediated by exploitative innovation. Apparently, slack resources that are available internally, such as human capital, flexible production process and idle capacity, are important for exploitative project. Internal slack is an additional resource that may be quickly deployed to offset sudden demands or new activities. This characteristic is fit with exploitative projects where most of the project elements are based on the existing or current knowledge and capability. Projects such as exploiting new feature or add new service on their offering can be performed with additional internal resources. Internal slack will ease small firms' restriction and improve the strategic choices for new project. It also allows experimentation with the exploitative project. 
Similarly the same finding was found in the case of the relationship between external slack and exploratory innovation. External slack is an additional resource that may be recovered from external organisations. To access external slack, small firms utilise their social networks and supporting partners such as incubators, university and other intermediaries' organisation. Compared to internal slack, external slack assure a predictable support that may facilitate new explorative projects. External slack in the forms of research facilities, access to researchers/students, and knowledge from university may endorse firms' activities in exploring new technology. Intermediary organisation may also support new knowledge for new market penetration. This benefit will promote an organisational focus on exploration and improve innovative capability by keeping communication with external organisation.

We believe that the findings contribute to deepening our understanding of the role of slack resources in supporting the innovation activities of small technology-based firms. Although the findings give even more credence to the importance of slack resources as a salient influence on firms' performance, our finding also suggest that this influence may be causally indirect. There are several theoretical and practical contributions of our study to existing work around small technology-based firms.

\section{Small technology-based firms need to understand the relationship between slack resources and innovation activities}

We respond to the need for more evidence that links resources, innovation and performance in the context of small technology-based firms. While previous research has asserted the importance of innovation, most studies overlooks the relationship between slack resources and innovation. Initially, small firms may be regarded as an organisation that suffers from limited resources. However, we have extended understanding to show how small firms use their flexible capacity to create slack resources and support exploratory and exploitative innovation. As we found in this study, slack resources play an important role in helping small technology-based firms perform their innovation activities. In addition, we have enriched the discussion by decomposing slack resources into two categories, internal and external slack. This categorisation provides an interesting finding where different types of slack actually effective in supporting different type of innovation activities.

Our finding supports the contingency theory (Venkataraman and Camillus, 1984) which posits that a co-alignment between resources and innovation activities leads to performance. When we tested for the direct effect of slack on performance, the effects were not significant. However, we found the effect of slack to be significant on performance, mediated by innovation activities. This suggests that slack resources alone do not determine performance. Rather, we find it is their coalignment that drives the performance of small technology-based firms. This finding is consistent with conceptual work that suggests the complexity in measuring the impact of slack resources. As previous studies are still inconclusive about the effects, we argue that only specialised resources tied to specific 
innovation activities are likely to form the firms' performance. In this case, it is internal slack together with exploitative innovation that yields to the successful performance whereas external slack and explorative innovation produce similar outcomes. Thus, our work contributes to the development of the contingency perspective by suggesting that slack resources when appropriately channelled through different innovation activities determine firm performance. This perspective also finds support from the stream of research examining the relationship of resource configuration, strategic choices and performance in the context of small firms (Chandler and Hanks, 1994; Yli-Renko et al., 2001).

Moreover, our findings confirm that small firms are not merely smaller versions of big businesses, the major distinguishing characteristics being their resource scarcity has forced them to acquire both internal and external resources. In the context of this study, internal and external slack play similar role which is supporting innovation activities. This result has an important interpretation. Small firms need to develop different slack resources if they want to become an ambidextrous organisation. However, developing both resources at the same times is a huge challenge. Given that small firms differ from larger firms in terms of organizational structures, leadership styles, reactions to the environments, available resources, and the internal contexts they operate, small firms need to develop managerial expertise to manage both resources. Previous studies (e.g. Hadjimanoli, 2000; Raisch and Birkinshaw, 2008; Kyriakopoulos and Moorman, 2004) found achieving organizational ambidexterity may be contingent on the availability of sufficient resources particularly as operating complexity grow and the need of critical resources such as managerial skills and capabilities, internal technological resources, increase.

\section{New policy for supporting innovation activities of small technology-based firms}

This study responds to the call for more policy-oriented research examining mechanisms that support the growth of small technology-based firms (Mian et al., 2016; Bruneel et al., 2012). Focusing on business incubators, this study provides a new insight on how support provided by business incubators plays a role in the innovation activities of firms. Currently, many incubators provide accommodations, shared services and access to pre-seed capital, as well as programs aimed at improving the entrepreneurial capabilities of founders. In the past few years, however, a critical debate has emerged on the role of the universities, especially with regard to the actual impact of their support to innovation activities (Mustar et al., 2008). The issue has been raised, because most European small technology-based firms tend to remain relatively small (Almus and Nerlinger, 1999). Despite many studies have been conducted to understand the barriers for innovation (e.g., Clarysse et al., 2005; Rothaermel and Thursby, 2005), the role of incubators in supporting innovation is still under studied. This study reveals that that external slack created as a result of incubation supports, help firms to take risks in pursuing exploratory innovation and provide firms with new growth potential. However, it should be align with the ability to perform exploitative innovation activities. Thus, this study triggers a new way of thinking in designing support policy for small technology-based firms. Depending on 
the needs of firms in performing explorative or exploitative innovations, support should be provided to increase access to the source of innovation such as university, research institute, and industry as well as develop internal firms' competence to generate and maintain resources. Accordingly, awareness needs to be increased about the life after incubation, particularly the potentially detrimental effects on maintaining slack resources that tend to occur if small technology-based firms graduate from the incubation programme.

\section{Limitation and recommendation for further study}

Like many empirical studies, this study has various limitations, which can be addressed in future research. A first limitation stems from the method of identifying slack resources. We chose to use the self-perception approach by asking the respondents about the presence and availability of slack resources. This implied a limitation in measuring the quantity and quality of resources, but - on the positive side - it also meant we focused on resources that really mattered and available for firms. In future research, a more precise measurement should be developed that potentially picturing a larger differentiation in slack resources. As many studies have measured slack using a financial measurement which may not be relevant for small firms, a new measurement for slack needs further exploration. Second, while we evaluated the role of innovation in transforming the impact of slack resources on performance, the relationship between them is clearly more nuanced. Future research could be devoted to a better insight into other relationships, in particular the role of slack in supporting firms' strategy (including marketing or management strategy). Future studies, using a larger set of organisational factors, could complement our results by examining the causality relationship between slack resources and performance. Finally, there are also limits in terms of the generalization of the results. The empirical study was carried out in the Netherlands, Norway and the United Kingdom, focused on small firms located at incubators, which means that the results may only apply to those firms that face a similar entrepreneurial support, and also a similar focus on sectors, namely technology-based sector. This means future research should look at general incubators, as well as other sectors (e.g. medium to low innovative firms) and other regions to complete the picture. We also suggest that further studies may consider testing the mediated model of slack resources in a different context, entrepreneurial firms without incubation support. 


\section{References}

Abernathy, W. J., \& Clark, K. B. (1985). Innovation: Mapping the winds of creative destruction. Research policy, 14(1), 3-22.

Afifi, A. A., \& Elashoff, R. M. (1966). Missing observations in multivariate statistics I. Review of the literature. Journal of the American Statistical Association, 61(315), 595-604.

Almus, M., \& Nerlinger, E. A. (1999). Growth of new technology-based firms: which factors matter?. Small business economics, 13(2), 141-154.

Baron, R. M., \& Kenny, D. A. (1986). The moderator-mediator variable distinction in social psychological research: Conceptual, strategic, and statistical considerations. Journal of personality and social psychology, 51(6), 1173.

Benner, M. J., \& Tushman, M. L. (2003). Exploitation, exploration, and process management: The productivity dilemma revisited. Academy of management review, 28(2), 238-256.

Boh, W. F., De-Haan, U., \& Strom, R. (2012). University technology transfer through entrepreneurship: faculty and students in spinoffs. The Journal of Technology Transfer, 1-9.

Bourgeois, L. J. (1981). On the measurement of organizational slack. Academy of Management review, 6(1), 29-39.

Bourgeois, L. J., \& Singh, J. V. (1983, August). Organizational Slack and Political Behavior Among Top Management Teams. In Academy of Management Proceedings (Vol. 1983, No. 1, pp. 4347). Academy of Management.

Bruneel, J., Ratinho, T., Clarysse, B., \& Groen, A. (2012). The Evolution of Business Incubators: Comparing demand and supply of business incubation services across different incubator generations. Technovation, 32(2), 110-121.

Chandler, G. N., \& Hanks, S. H. (1994). Market attractiveness, resource-based capabilities, venture strategies, and venture performance. Journal of business venturing, 9(4), 331-349.

Chang, Y. Y., \& Hughes, M. (2012). Drivers of innovation ambidexterity in small-to medium-sized firms. European Management Journal, 30(1), 1-17.

Chattopadhyay, P., Glick, W. H., \& Huber, G. P. (2001). Organizational actions in response to threats and opportunities. Academy of Management Journal,44(5), 937-955.

Chen, M. J., \& Hambrick, D. C. (1995). Speed, stealth, and selective attack: How small firms differ from large firms in competitive behavior. Academy of management journal, 38(2), 453-482.

Cheng, J. L., \& Kesner, I. F. (1997). Organizational slack and response to environmental shifts: The impact of resource allocation patterns. Journal of management, 23(1), 1-18.

Chrisman, J. J., Bauerschmidt, A., \& Hofer, C. W. (1998). The determinants of new venture performance: An extended model. Entrepreneurship Theory and Practice, 23, 5-30.

Clarysse, B., Wright, M., Lockett, A., Van de Velde, E., Vohora, A., 2005. Spinning out new ventures: a typology of incubation strategies from European research institutions. Journal of Business Venturing, 20(2), 183-216. 
Colombo, M. G., \& Delmastro, M. (2002). How effective are technology incubators?: Evidence from Italy. Research policy, 31(7), 1103-1122.

Covin, J. G., \& Slevin, D. P. (1989). Strategic management of small firms in hostile and benign environments. Strategic management journal, 10(1), 75-87.

Cyert, R. M., \& March, J. G. (1963). A behavioral theory of the firm. Englewood Cliffs, NJ, 2.

Dalton, D. R., Todor, W. D., Spendolini, M. J., Fielding, G. J., \& Porter, L. W. (1980). Organization structure and performance: A critical review. Academy of Management Review, 5(1), 49-64.

Damanpour, F. (1991). Organizational innovation: A meta-analysis of effects of determinants and moderators. Academy of management journal, 34(3), 555-590.

Daniel, F., Lohrke, F. T., Fornaciari, C. J., \& Turner, R. A. (2004). Slack resources and firm performance: a meta-analysis. Journal of Business Research, 57(6), 565-574.

Danneels, E. (2002). The dynamics of product innovation and firm competences. Strategic management journal, 23(12), 1095-1121.

Ebben, J. J., \& Johnson, A. C. (2005). Efficiency, flexibility, or both? Evidence linking strategy to performance in small firms. Strategic management journal,26(13), 1249-1259.

Edelman, L. F., Brush, C. G., \& Manolova, T. (2005). Co-alignment in the resource-performance relationship: strategy as mediator. Journal of Business Venturing, 20(3), 359-383.

Finkelstein, S., \& Hambrick, D. C. (1990). Top-management-team tenure and organizational outcomes: The moderating role of managerial discretion.Administrative science quarterly, 484503.

Galbraith, J. R. (1974). Organization design: An information processing view.Interfaces, 4(3), 28-36.

George, G. (2005). Slack resources and the performance of privately held firms. Academy of Management Journal, 48(4), 661-676.firms. Small Business Economics, 39(2), 495-515.

Greve, H. R. (2007). Exploration and exploitation in product innovation.Industrial and Corporate Change, 16(5), 945-975.

Hadjimanolis, A. (2000). A resource-based view of innovativeness in small firms. Technology analysis \& Strategic management, 12(2), 263-281.

Hair, J.F., Anderson, R.E., Tatham, R.L., Black, W.C. (1995) Multivariate Data Analysis with Readins, $4^{\text {th }}$ Ed. Prentice-Hall, Upper Saddle River, NJ.

Hambrick, D. C., \& Snow, C. C. (1977, August). A Contextual Model of Strategic Decision Making in Organizations. In Academy of Management Proceedings (Vol. 1977, No. 1, pp. 109-112). Academy of Management

He, Z. L., \& Wong, P. K. (2004). Exploration vs. exploitation: An empirical test of the ambidexterity hypothesis. Organization science, 15(4), 481-494.

Herold, D. M., Jayaraman, N., \& Narayanaswamy, C. R. (2006). What is the relationship between organizational slack and innovation?. Journal of Managerial Issues, 372-392.

Hoyle, R. (1995) Structural Equation Modeling. Sage Publications. Thousand Oaks, CA. 
Hughes, M., Martin, S. L., Morgan, R. E., \& Robson, M. J. (2010). Realizing product-market advantage in high-technology international new ventures: The mediating role of ambidextrous innovation. Journal of International Marketing,18(4), 1-21.

Kyriakopoulos, K., \& Moorman, C. (2004). Tradeoffs in marketing exploitation and exploration strategies: The overlooked role of market orientation. International Journal of Research in Marketing, 21(3), 219-240.

Lamine, W., Mian, S., \& Fayolle, A. (2014). How do social skills enable nascent entrepreneurs to enact perseverance strategies in the face of challenges? A comparative case study of success and failure. International Journal of Entrepreneurial Behavior \& Research, 20(6), 517-541.

Jansen, J. J., Van Den Bosch, F. A., \& Volberda, H. W. (2006). Exploratory innovation, exploitative innovation, and performance: Effects of organizational antecedents and environmental moderators. Management science, 52(11), 1661-1674.

Jensen, M.C., (1986). Agency costs of free cash flow, corporate finance and take overs, American Economic Review, 76. 323-329.

Kleinbaum, D.G., Kupper, L.L., Muller, K.E. (1988) Applied Regression analysis and Other Multivariate Methods. Duxburry Press, Belmont. CA.

Kleine, R.B. (1998) Principles and Practices of Structural Equation Modeling. The Guildford Press, New York, NY.

Lamine, W., Jack, S., Fayolle, A., \& Chabaud, D. (2015). One step beyond? Towards a process view of social networks in entrepreneurship. Entrepreneurship \& Regional Development, 27(7-8), 413-429.

Levinthal, D., \& March, J. G. (1981). A model of adaptive organizational search. Journal of Economic Behavior \& Organization, 2(4), 307-333.

Löfsten, H., \& Lindelöf, P. (2005). R\&D networks and product innovation patterns-academic and non-academic new technology-based firms on Science Parks. Technovation, 25(9), 1025-1037.

Lubatkin, M. H., Simsek, Z., Ling, Y., \& Veiga, J. F. (2006). Ambidexterity and performance in small-to medium-sized firms: The pivotal role of top management team behavioral integration. Journal of management, 32(5), 646-672.

Mansfield, E. (1963). Size of firm, market structure, and innovation. The Journal of Political Economy, 556-576.

March, J.G, \& simon, H.A. (1958) Organizations, New York: Willey.

March, J. G. (1991). Exploration and exploitation in organizational learning.Organization science, 2(1), 71-87.

Mian, S., Fayolle, A., \& Lamine, W. (2012). Building sustainable regional platforms for incubating science and technology businesses Evidence from US and French science and technology parks. The International Journal of Entrepreneurship and Innovation, 13(4), 235-247. 
Mian, S., Lamine, W., \& Fayolle, A. (2016). Technology Business Incubation: An overview of the state of knowledge. Technovation, 50, 1-12.

Mustar, P., Wright, M., Clarysse, B., 2008. University spin-off firms: Lessons from ten years of experience in Europe. Science and Public Policy, 35(2), 67-80.

Muthén, L. K., \& Muthén, B. O. (2002). How to use a Monte Carlo study to decide on sample size and determine power. Structural Equation Modeling,9(4), 599-620.

Nelson, R. R., \& Sidney, G. Winter (1982). An evolutionary theory of economic change, 929-964.

Newbert, S. L. (2005). New Firm Formation: A Dynamic Capability Perspective. Journal of small business management, 43(1), 55-77.

Nohria, N., \& Gulati, R. (1996). Is slack good or bad for innovation?. Academy of management Journal, 39(5), 1245-1264.

Nooteboom, B., Berger, H., \& Noorderhaven, N. G. (1997). Effects of trust and governance on relational risk. Academy of management journal, 40(2), 308-338.

Nunnally, J. (1978). Psychometric Theory. New York: McGraw-Hill.

O'Reilly III, C. A., \& Tushman, M. L. (2011). Organizational ambidexterity in action: How managers explore and exploit. California Management Review,53(4), 5-22.

Penrose, E. T. (1995). The Theory of the Growth of the Firm. Oxford university press.

Peters, L., Rice, M., \& Sundararajan, M. (2004). The role of incubators in the entrepreneurial process. The Journal of Technology Transfer, 29(1), 83-91.

Phan, P. H., Siegel, D. S., \& Wright, M. (2005). Science parks and incubators: observations, synthesis and future research. Journal of business venturing, 20(2), 165-182.

Raisch, S., \& Birkinshaw, J. (2008). Organizational ambidexterity: Antecedents, outcomes, and moderators. Journal of management.

Raisch, S., Birkinshaw, J., Probst, G., \& Tushman, M. L. (2009). Organizational ambidexterity: Balancing exploitation and exploration for sustained performance. Organization Science, 20(4), 685-695.

Rothaermel, F. T., \& Deeds, D. L. (2004). Exploration and exploitation alliances in biotechnology: a system of new product development. Strategic management journal, 25(3), 201-221.

Rothaermel, F.T., Thursby, M., (2005). Incubator firm failure or graduation?: The role of university linkages. Research Policy, 34(7), 1076-1090.

Schumacker, R.E., Lomax, R.G. (1996) A Beginner's Guide to Structural Equation Modeling. Lawrence Erlbaum. Mahwah, $\mathrm{Nj}$.

Sharfman, M. P., Wolf, G., Chase, R. B., \& Tansik, D. A. (1988). Antecedents of organizational slack. Academy of Management Review, 13(4), 601-614.

Sheremata, W. A. (2000). Centrifugal and centripetal forces in radical new product development under time pressure. Academy of management review,25(2), 389-408. 
Singh, J. V. (1986). Performance, slack, and risk taking in organizational decision making. Academy of management Journal, 29(3), 562-585.

Smith, K. G., Grimm, C. M., Gannon, M. J., \& Chen, M. J. (1991). Organizational information processing, competitive responses, and performance in the US domestic airline industry. Academy of Management Journal, 34(1), 60-85.

Shrout, P. E., \& Bolger, N. (2002). Mediation in experimental and nonexperimental studies: new procedures and recommendations. Psychological methods, 7(4), 422.

Stroh, L. K., Brett, J. M., Baumann, J. P., \& Reilly, A. H. (1996). Agency theory and variable pay compensation strategies. Academy of Management Journal, 39(3), 751-767.

Tan, J., \& Peng, M. W. (2003). Organizational slack and firm performance during economic transitions: Two studies from an emerging economy. Strategic Management Journal, 24(13), 1249-1263.

Teece, D. J. (2010). Business models, business strategy and innovation. Long range planning, 43(2), 172-194.

Turner, N., Swart, J., \& Maylor, H. (2013). Mechanisms for managing ambidexterity: a review and research agenda. International Journal of Management Reviews, 15(3), 317-332.

Tushman, M. L., \& O’Reilly III, C. A. (2006). Ambidextrous organizations: Managing evolutionary and revolutionary change. Managing innovation and change, 170.

Rosner, M. M. (1968). Economic determinants of organizational innovation. Administrative Science Quarterly, 614-625.

Venkatraman, N. (1989). The concept of fit in strategy research: Toward verbal and statistical correspondence. Academy of management review, 14(3), 423-444.

Venkatraman, N., \& Camillus, J. C. (1984). Exploring the concept of "fit" in strategic management. Academy of Management Review, 9(3), 513-525.

Voss, G. B., Sirdeshmukh, D., \& Voss, Z. G. (2008). The Effects of Slack Resources and Environmentalthreat on Product Exploration and Exploitation. Academy of Management Journal, 51(1), 147-164.

Voss, G. B., \& Voss, Z. G. (2013). Strategic ambidexterity in small and medium-sized enterprises: implementing exploration and exploitation in product and market domains. Organization Science, 24(5), 1459-1477.

Wadhwa, A., \& Kotha, S. (2006). Knowledge creation through external venturing: Evidence from the telecommunications equipment manufacturing industry. Academy of Management Journal, 49(4), 819-835.

Westhead, P., \& Storey, D. J. (1994). An assessment of firms located on and off science parks in the United Kingdom. London, UK. 
Yli-Renko, H., Autio, E., \& Sapienza, H. J. (2001). Social capital, knowledge acquisition, and knowledge exploitation in young technology-based firms. Strategic management journal, 22(67), 587-613. 